\title{
Challenge of Sport Towards Social Inclusion and Awareness-Raising Against Any Discrimination
}

\section{Authors' contribution:}

A) conception and design of the study

B) acquisition of data

C) analysis and interpretation of data

D) manuscript preparation

E) obtaining funding

\section{Salomé Marivoet}

Lusophone University of Humanities and Technologies, Portugal

\section{ABSTRACT}

Sport presents itself as a social configuration that enhances social inclusion by promoting tolerance, respect for others, cooperation, loyalty and friendship, and values associated with fair play, the most important ethical principles of sport. However, intolerance and exclusion can also be expressed in sport, certainly even more so the bigger the social inequalities and the ethnic, religious, gender, disability, and sexual orientation prejudices are in society.

The processes of social exclusion, integration, and inclusion are research areas in the social sciences with consolidated knowledge, namely in the study of the problems of poverty, social inequalities, racial and ethnic discrimination, disability, and education. However, it is necessary to discuss the existing theoretical approaches and conceptions seen as explanatory principles of the reality of these fields of analysis, look at how they can frame the reality on the sports field, and then confirm them through empirical research in order to produce knowledge based on the reality of social facts.

Despite the broad consensus on the potential of sport in promoting social inclusion, in this paper I stress that this potential can only become real if the orientation of sport includes strategies aimed at achieving these goals. I intend to show how the "social issue" in the field of sports has gained relevance in the institutional context, and thereby a new field of research for the social science of sport has been opened and needs to be deepened.

KEYWORDS sport, values, social inclusion, exclusion, discrimination

\section{Introduction}

In current times, which are marked by globalization, the cultural walls between peoples are tending to fade and human diversity is becoming visible. However, parallel to this trend, we are watching the reaffirmation of identities and cultures (Maffesoli, 1988; Friedman, 2000), in some cases taking forms of radicalism and hostility and, therefore, the acuity of the value of tolerance and social inclusion.

Currently, it is consensual that sport is a cultural phenomenon with huge potential in bringing people, cultures, and nations together, either through fostering sociabilities or conveying identitary senses of belonging, as several authors have remarked. In fact, the sport fis a social space in which people can feel a part, and sport, therefore, has the potential for social inclusion. 
In addition, the ethics of sport and the fundamental principles of Olympism expressed in the Olympic Charter precisely convey values associated with the principles of fair play that guide sporting action towards inclusion and fight all types of discrimination.

Since the second half of the twentieth century, the ideals of sport for all have served as the background of public sports policies, initially encouraged by the Council of Europe (the European Charter of Sport for All of 1975, followed by the European Charter of Sport of 1992, reviewed in 2001 ${ }^{1}$ ), and more recently by the European Union, and thus sport has risen to being the right of every citizen.

In 2007, precisely in the same year of the signing of the Treaty of Lisbon, the European Commission launched the White Paper on Sport ${ }^{2}$, in which it proposes a common European sports policy in defense of what is called the European Sports Model. In this strategic European sports policy document, which stresses the societal role of sport, the use of the potential of sport in promoting social inclusion, in the establishment of equal opportunities, and in the prevention and fight against racism and any kind of discrimination is encouraged.

Resulting from the safeguard of the enshrined principles of dignity, freedom, equality, and solidarity in the Charter of Fundamental Rights of the European Union since $2000^{3}$, the fight against all kinds of discrimination, as well as the promotion of tolerance and social inclusion, became part of the EU's political agenda. The Agency for Fundamental Rights (FRA) was created in 2008 as the body of the EU whose mission is to observe and prevent the violation of these principles.

In addition, in July 2008 the European Commission published a Special Eurobarometer on Discrimination in the European Union: Perceptions, Experiences and Attitudes ${ }^{4}$, with the results of a survey conducted in March of the same year which concluded that $62 \%$ of Europeans believe discrimination exists in their country due to ethnicity, $51 \%$ due to sexual orientation, $45 \%$ due to disability, $42 \%$ respectively due to age and religion or belief, and $36 \%$ due to gender. As we see, the perception of discrimination of Europeans reveals that the EU still has a long way to go to ensure the fundamental rights of dignity, freedom, equality, and solidarity are really effective.

As the authors of exclusion and social inequalities have concluded (for example, Robert Castel with the introduction of the notion of the "new social issue" associated with precarious work), the forms of discrimination tend to be multiple and are associated with the social characteristics of people, in particular their social vulnerability associated with economic and social disadvantages, including the cultural and symbolic; realities exacerbated in times of crisis, as present times show. In addition, the multiculturality present in the EU associated with rising of unemployment and crime has allowed intolerance based on ethnic origin to resurface, which is a concern for the cohesion and security of European citizens.

\footnotetext{
${ }^{1}$ Council of Europe (Recommendation No. R (92) 13 REV). European Sports Charter. Retrieved April 28, 2014, from https://wcd.coe.int/ViewDoc.jsp?Ref=Rec(92)13\&Sector=secCM\&Language=lanEnglish\&Ver=rev\&BackColorInterne $\mathrm{t}=9999 \mathrm{CC} \&$ BackColorIntranet=FFBB55\&BackColorLogged $=$ FFAC75

${ }^{2}$ Commission of the European Communities (Brussels, 11.7.2007, COM (2007) 391 final). White Paper On Sport. Retrieved April 28, 2014, from http://eur-lex.europa.eu/legal content/EN/TXT/PDF/?uri=CELEX:52007DC0391\&from=EN

${ }^{3}$ Official Journal of the European Communities (2000/C 364/01). Charter Of Fundamental Rights Of The European Union. Retrieved April 28, 2014, from http://www.europarl.europa.eu/charter/pdf/text_en.pdf

${ }^{4}$ European Commission (Fieldwork February - 2008, March; Publication 2008, July). Special Eurobarometer 296 on Discrimination in the European Union: Perceptions, Experiences and Attitudes. Retrieved April 28, 2014, from http://ec.europa.eu/public_opinion/archives/ebs/ebs_296_en.pdf
} 
Nevertheless, during 2004, the European Year of Education through Sport, the European Commission published a report on Studies on Education and Sport. Sport and Multiculturalism ${ }^{5}$. The studies reinforced the fact that public policies on inclusion and the prevention of discrimination, abuse, and exclusion will be needed. Therefore, in 2008, the FRA created its first Observatory on Racism, Xenophobia and Related Intolerance, and the following year promoted a study aimed at identifying these discriminatory practices in sport, as well as initiatives of good prevention practices.

In the findings of a study entitled Racism, Ethnic Discrimination and Exclusion of Migrants and Minorities in Sport. A Comparative Overview of the Situation in the European Union, published in October 2010 by FRA ${ }^{6}$, in which I participated as a researcher in the team lead by Fair Play at the Vienna Institute for International Dialogue and Cooperation (VIDC), we identified the forms of structural or normative discrimination leading to exclusion and direct discrimination, meaning aggression or other acts violating the dignity of the athletes, in particular racist and xenophobic behavior.

This study, promoted by FRA, was based on 27 national studies that were conducted by the National Focal Points (NFPs) of the RAXEN Network, with each study covering secondary data and information from official and unofficial sources, as well as academic research and online media archives from the reference period 2003-2008; research for each thematic study included a minimum of seven semi-structured interviews with key experts and stakeholders (representatives of sport federations, athletes' organizations, and NGOs). In addition, questionnaires were sent out to key stakeholders governing European sport as well as to the national sports associations of the researched sports.

Different levels of sport were analyzed in the course of the this study, such as adult professional, amateur, and grassroots sports for men and women, as well as children and youth sport for girls and boys. The study also presents an overview on actors and measures on the European level as well as on national and European preventive initiatives and models of good practice.

Despite the general consensus on the potential of inclusive sport in to promote experiences of social interaction on the basis of mutual respect and equality around the sense of belonging to the group (particularly for young people from disadvantaged families or subjected to any kind of discrimination); the examples of exclusion in sport continue to happen, certainly how much greater are the inequalities and prejudices of ethnic, religious, gender, disability, and sexual orientation in each society.

If on the one hand, sport presents itself as a social configuration in the sense assigned by Elias and Dunning (1986), it enhances the social inclusion by promoting tolerance, respect for others, cooperation, loyalty and friendship, and values associated with fair play, which are the most important ethical principles of sport (Arnold, 1998; Simon, 2004; Marivoet, 2010); on the other hand, intolerance and exclusion can also be expressed in sport, namely racial and ethnic discrimination (Kassimeis, 2008; Hylton, 2009). Thereby, the importance that has been given by the authorities and EU bodies to promote and disseminate initiatives are considered positive for social inclusion.

If at the level of sports policies we find exact strategic orientations with a view to promoting "inclusive sport" through the creation and the development of projects on the field (Marivoet, 2012), in the academic space, the theme or issue of social inclusion through sport is still rather marginal when compared to areas of interest of researchers in the social science of sport.

Placing ourselves in a utilitarian perspective with respect to social sciences, or in other words, that the knowledge produced will contribute to the improvement of human relationships, although preserving its scientific neutrality, and therefore moving away from any kind of social engineering, we can question their

\footnotetext{
${ }^{5}$ European Commission: DG Education \& Culture (2004, August). Studies On Education And Sport Sport And Multiculturalism (LOT 3) Final Report. Retrieved April 28, 2014, from http://www.iscaweb.org/files/Sport\%20and\%20Multiculturalism\%20EU\%202004.pdf

${ }^{6}$ European Union Agency for Fundamental Rights (2010, October). Racism, ethnic discrimination and exclusion of migrants and minorities in sport: A comparative overview of the situation in the European Union. Retrieved April 28 , 2014, from http://fra.europa.eu/fraWebsite/attachments/Report-racism-sport_EN.pdf
} 
relevance in this area of social intervention, or what the contribution of scientific knowledge is in this regard. It is, in my view, a new field of research in the social science of sport, and several challenges appear at once in the search for theoretical approaches and concepts, and its explanatory principles of social processes. This knowledge is essential for better understanding the social facts under analysis, which will certainly contribute to the precision and achievement of the goals of ongoing or future projects, as well as for the assessment of the results achieved.

\section{Conceptual Approach to the Subject}

The processes of social exclusion, integration, and inclusion are research areas in the social sciences, particularly in the fields of sociology, psychology, and social and solidarity economy, which have a consolidated knowledge, namely in the study of the problems of poverty, social inequalities, racial or ethnic discrimination, disability, and education. However, it will be necessary to discuss the existing theoretical approaches or conceptions seen as explanatory principles of the reality of these fields of analysis, so that they can frame the reality on the sports field, and subject them to empirical research in order to produce knowledge based on the reality of social facts.

Revisiting the notion of anomie by Émile Durkheim (1975), Robert Castel (1998) considers that social exclusion is a form of "disaffiliation", resulting from the loss of participation in the productive activity associated with social isolation. The author also considers that social vulnerability is an unstable intermediary zone that combines precarious work and the fragility of proximity supports. Thus, the sphere of work is, for this author, central to the cohesion of the social structure, and as a result inserts social inequalities in the processes of exclusion and loss of citizenship. Still, the notion of "disaffiliation" associated with the loss of citizenship and exclusion seems to have some potential in the study of the processes of exclusion in sport, and is opposed to social inclusion; in this last case, making use of the notion of affiliation is associated with the exercise of citizenship, precisely because sport is a social space oriented to the creation of sociability and civic participation networks, in the production and reproduction of various identities, including the territorial and national, as various authors have shown (Dauncey \& Hare, 1999; Finn \& Giulianotti, 2000; Miller et al., 2001; Giulianotti \& Robertson, 2007; Marivoet, 2006a, 2006b).

In addition, the sociological concept of social capital has enormous potential in the conceptualization of the problem in the field of sport. Initially proposed by Pierre Bourdieu $(1979,1980,1985)$, it has been developed by other authors, including Robert Putnam, in the comparative study of the development of communities, and by James Coleman as a resource in achieving the goals and satisfaction of personal interests, as Portes (2000) and Almeida (2011) pointed out in their works on social capital.

Going into rupture with traditional Marxist approaches in the study of social classes that privilege the place of individuals in the productive sphere and the ownership of the means of production in social stratification, Pierre Bourdieu (1979) introduced the concepts of economic, cultural, and social capital in the analysis of the production and reproduction processes of class identities. Additionally, the personal preferences or likes and cultural practices constituted indicators of class position or of a fraction thereof, in which Bourdieu included the sporting habits. In developing this approach, Christian Pociello (1987) added the body capital, and in a previous work I used the notion of sports capital as a resource that could be used by individuals (Marivoet, 1997a, 1997b).

In the constituent elements of social capital, Bourdieu identified the networks of social relationships that allow individuals to have access to the resources of the group or the network members and the quantity and quality of the group's resources. According to Bourdieu, the relationships established between individuals do not result only from the sharing of objective relationships or from the same socioeconomic space, but from the material and symbolic exchanges, whose establishment and perpetuation requires recognition of this proximity.

The clubs or sports organizations present themselves precisely as spaces of creation of social networks producing social capital, as happens in other spheres of social life, such as family, school, church, etc. It is 
therefore through these social networks that the individual acquires feelings of belonging, of being part of society, and therefore of inclusion.

Pierre Bourdieu also drew attention to the fact that the benefits obtained by individuals through the participation in groups or social networks, namely the ability of social capital to be transformed into cultural or economic capital, and in the case of sports activities we could add body and sports capital, enhancing sport as a place of inclusion resource production. From the conceptual point of view, this approach allows us to guide the research, although it lacks more consolidated empirical evidence and, therefore, it is necessary to expand and diversify the study of the reality.

The monitoring of cases of exclusion and discrimination in sport, with a view to assessing their dimension and impact on society, as well as the understanding of the nature and processes that underlie it, presents itself as an opportunity to study, in my point of view, crucial to the development of the empirical knowledge of reality, as the above-mentioned study by the FRA concluded. However, given the investment required by these studies in terms of means and human resources, it will only be possible to implement them with financing, which could be an obstacle, especially when there is no interest in this type of national funding programs for scientific research, at least in Portugal.

Obviously, the knowledge produced in these Observatories would allow deepening of the forms and processes of exclusion and discrimination that occur in sport, knowledge crucial to provide support for programs and projects that promote inclusive sports on the field, as well as support the sports policies aimed at its promotion. In addition, the monitoring of ongoing projects of inclusive sport, with the development of studies enabling the assessment of the effectiveness and scope of the implemented processes, would result in a surplus value to knowledge in this field of intervention, and thus find validated criteria to identify good practices of "social inclusion in sport" and "social inclusion through sport".

\section{Social Inclusion in and through Sport}

Having as reference my experience in European projects, there is a broad consensus at institutional level on the notions of "social inclusion in sport" and "inclusion through sport." Social inclusion in sport means the actual existence of equal opportunities in its access. Good practices are the promotion of widespread sports, and the presence of people that tend to be excluded in society from the development of leadership and technical activities, this is, that no discrimination exists in the access to these positions based on racial, ethnic, religious, disability, gender, sexual orientation, social class grounds, or others.

In its turn, social inclusion through sport refers to the development of personal, social, motor, or other skills, in which good practices are aimed at promoting formative sport, which mean privileging the ethical principles of sport and related values associated with sport in children and young people in school or those at risk of discrimination, as the works of Sherry (2010) and Haudenhuyse, Theeboom, and Nols (2012) have shown.

Although lacking more theoretical discussion, these pre-notions provide orientation in research areas at the macro and micro level of the social reality. For example, at the micro level, research-action is a possibility of study aimed at specific intervention projects on the field, or even the orientation of sporting activity within groups or teams with a view to social inclusion, whose results can become very fruitful in the study of the potential of sport as a tool for social inclusion, particularly at the level of know-how how to promote inclusion, and enhance skills that go beyond mere motor or sports skills.

\section{Case Studies of Research-Action}

I have been promoting a research line for the past two years with bachelor and master students in Lusófona University, and even though it has not yet allowed the production of systematic knowledge, the findings of the conducted case studies have pointed to the effectiveness of inclusive strategies adopted by sports coaches or trainers in the universes under study. Basically, these case studies oriented towards young 
people have been developed in teams of sports clubs, sports groups inserted in community programs, and in classes in schools.

As methodological assumptions, these case studies directed to the research-action (Sanches, 2005) include the analysis of the structure of a group, using sociometric tests (Northway \& Weld, 1999) in order to identify cases of exclusion. It is from this analysis that the inclusive strategies to be implemented by coaches or teachers through sports interaction are defined, with subsequent assessment. The strategies aim at creating situations for bringing young people together in the space of sports interaction, creating "stages of proximity," as we call them, where excluded or self-excluded young people come into interaction with others.

It is thus intended to tear down the walls of affection that generally tend to be built by social prejudices that lead to rejection behavior and attitudes among children and young people, and thus generate "affiliation" and enhance "social capital" and the sense of belonging, of being part, of participating, and thus experience the exercise of citizenship. The inclusive experiences shared in the space of sports interaction and the individual skills acquired are analyzed through self-representations of the social actors involved. Obviously, for a greater understanding of the phenomenon it will be necessary to combine this subjective analysis with objective analysis, for example, by expanding the universes of analysis to families and teachers, a procedure that has proved difficult to put in practice in all of the case studies, but that we are introducing whenever possible.

\section{Good Practice of Social Inclusion through Sport across Europe}

Over the years, a wide range of projects has been implemented to promote inclusive sport in EU countries, although they have not been significantly studied. In the national RAXEX reports that were the basis for the above-mentioned FRA study, we found 264 good practice initiatives of social inclusion in and through sport, developed between 2003 and 2008 in the 27 EU member states. These initiatives were selected in each country according to the goals, rather than according to their impact on the target populations, without taking into account assessment studies or research serving as justification for their scope.

As shown in Chart 1,73\% of these positive initiatives addressed the problem of racism and xenophobia; $31 \%$ other intolerance (identified in Chart 2 below); $28 \%$ the problem of under-representation of minorities; $10 \%$ anti-gypsyism; $7 \%$ anti-Semitism; and finally, $2 \%$ the problem of Islamophobia.

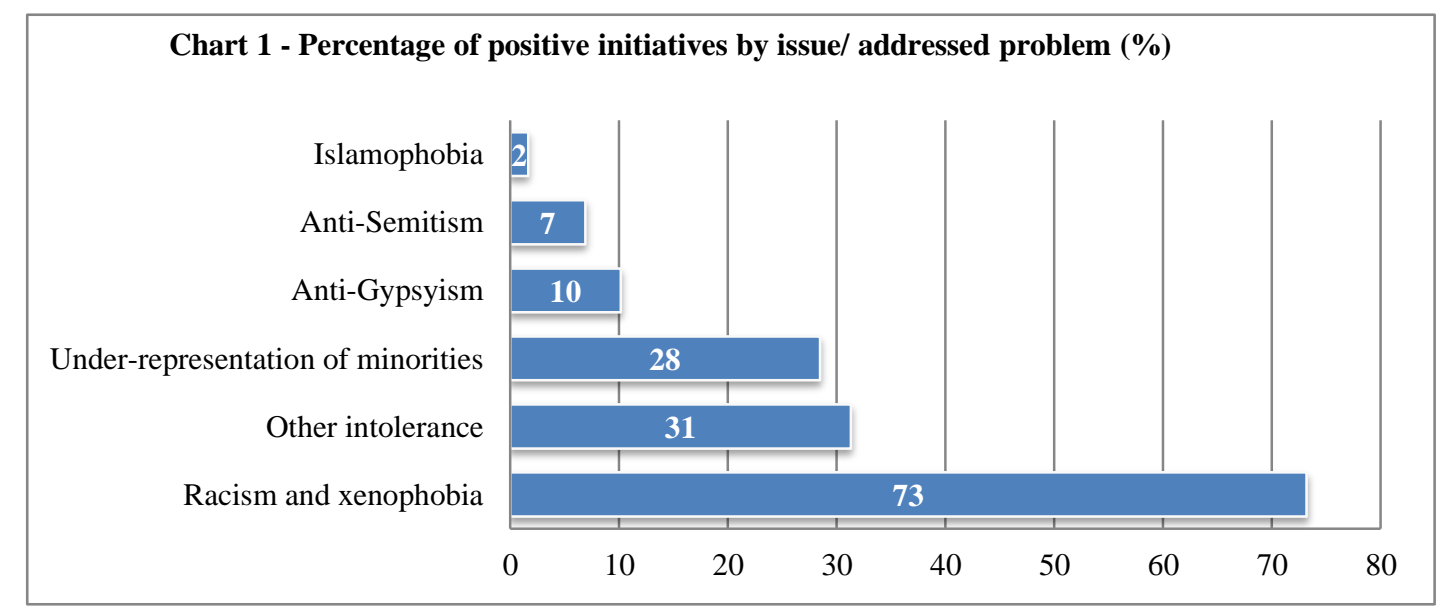

Source: FRA RAXEN National Thematic Studies, Preventing Racism, Xenophobia and Related Intolerance in Sport in the European Union, Vienna, 2009.

As Chart 2 shows, regarding "other intolerance" ( $31 \%$ of the total, from Chart 1), the social exclusion of unprivileged group was attended by the largest number of initiatives (29.9\%), followed by sexism/gender 
segregation (15,6\%), regulation of conflicts/commitments and violence (both 10.4\%), and religious sectarianism $(9.1 \%)$.

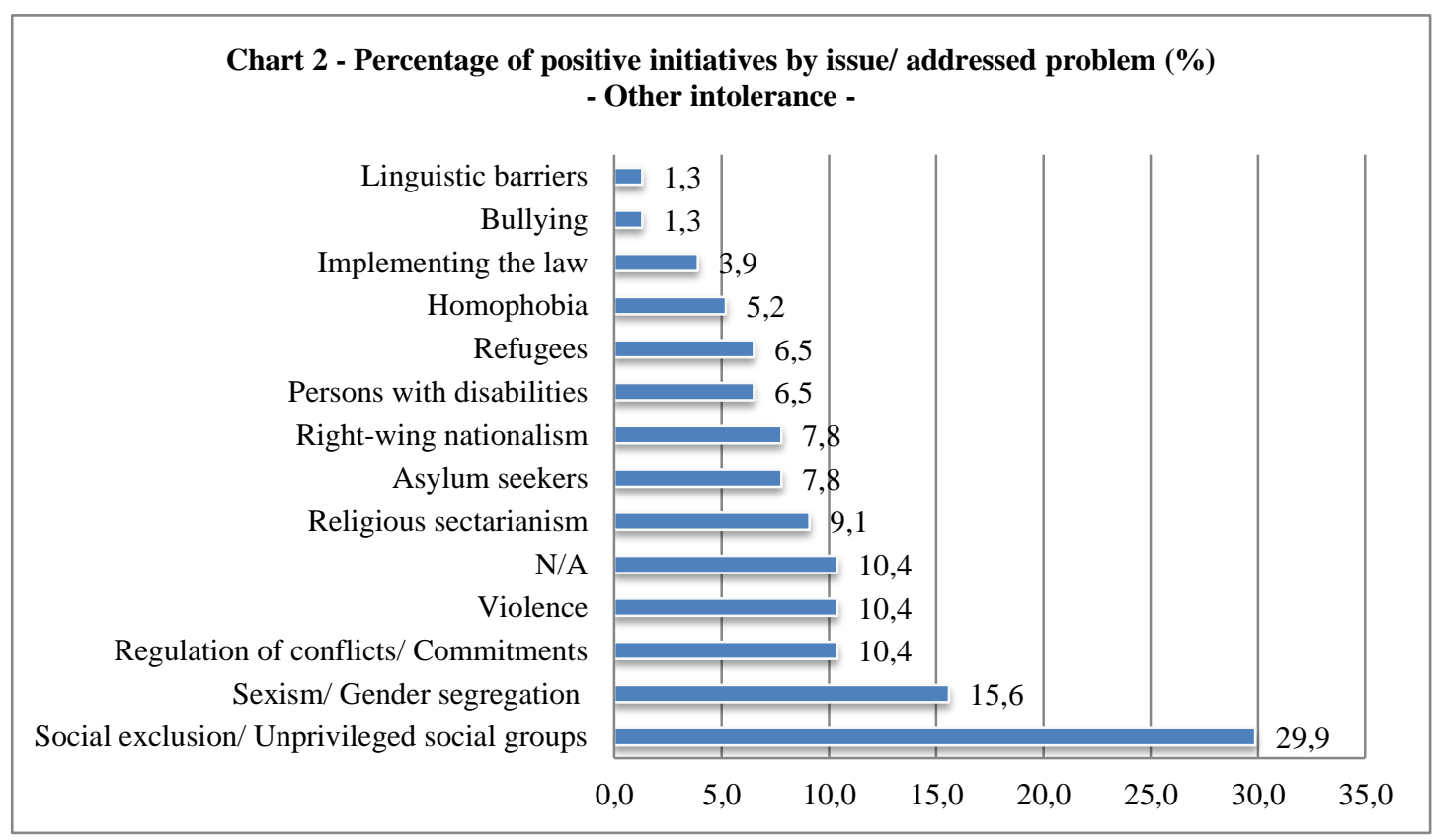

Source: FRA RAXEN National Thematic Studies, Preventing Racism, Xenophobia and Related Intolerance in Sport in the European Union, Vienna, 2009.

The problems of exclusion and discrimination addressed by these positive initiatives have a relation to the findings of the Special Eurobarometer on Discrimination in 2008, which concerns the problem of racism and xenophobia. As pointed out above, $62 \%$ of Europeans believe discrimination exists in their country due to ethnicity. However, the relation is to a lesser degree to the other exclusions or discriminations problems, or at least the perceptions, experiences, and attitudes of the problem by Europeans. As we remarked in the introduction to this paper, $51 \%$ of Europeans believe discrimination exists in their country due to sexual orientation, $45 \%$ due to disability, $42 \%$ respectively due to age and religion or belief, and $36 \%$ due to gender.

As can be seen in Chart 3, more than half of the organizations that promote these good practice initiatives are sports (54\%). Still, the promoters of initiatives are diverse, meeting a high percentage of nongovernmental organizations of solidarity and social services $(45 \%)$, as well as public or government organizations $(31 \%)$.

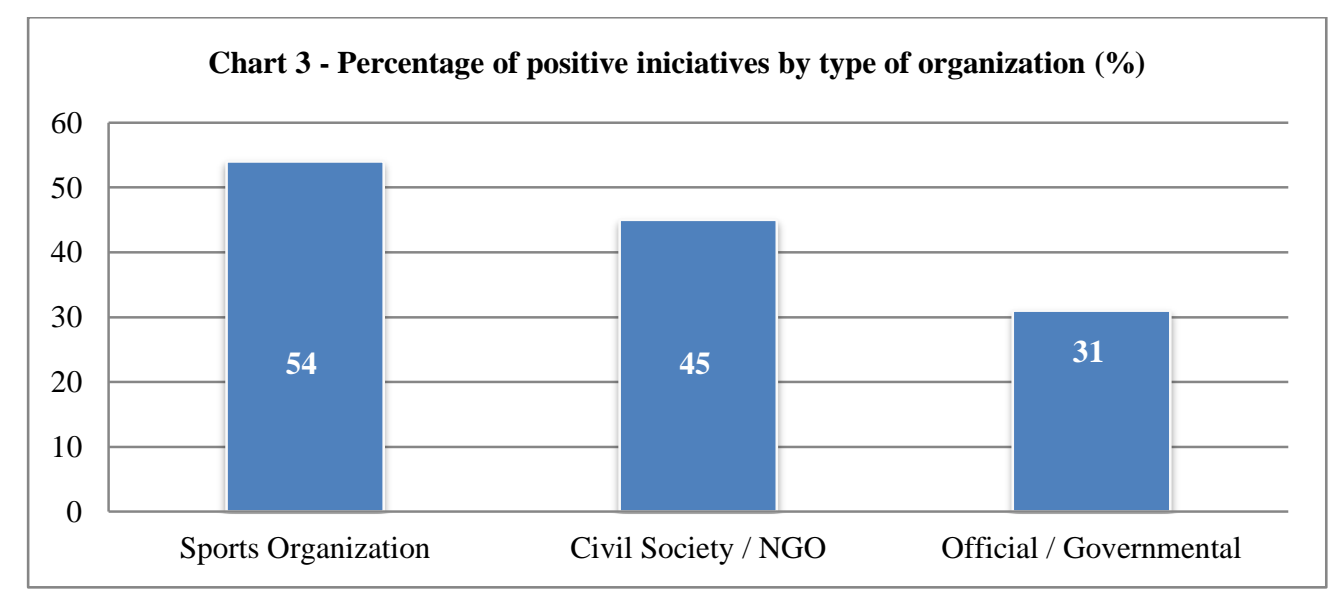

Source: FRA RAXEN National Thematic Studies, Preventing Racism, Xenophobia and Related Intolerance in Sport in the European Union, Vienna, 2009. 
As we see, within the EU, the first decade of the $21^{\text {st }}$ century was marked by emphasis on the social and educational role of sport, as evidenced by the European Year of Education through Sport in 2004. During the European Year for Combating Poverty and Social Exclusion in 2009, one of the projects selected by the European Commission was Sport Inclusion Network (SPIN) ${ }^{7}$, which brought together sports organizations and NGOs from seven European countries.

In addition to the training and awareness-raising actions in each of the seven countries, the SPIN network organized two European events; the first in 2011, the conference Challenging Social Exclusion in and through Sport, in Vienna; and the second, held on the occasion of the Winter Youth Olympic Games in 2012, the Seminar Involving Young Migrants in Winter Sports, in Innsbruck.

Among the SPIN initiatives, we can also list the preparation and publication of A Guide to Good Practice on Inclusion of Migrants in and through Sports ${ }^{8}$, which gathered more than 40 good examples. Although the selection criteria include the effects/impacts of the projects, in most cases, these continued not to be supported by independent or academic studies using research methodologies, a fact that highlights the need for social researchers of sport to take an interest in this study area.

\section{Final remarks}

I would like to stress that despite the broad consensus on the potential of sport in promoting social inclusion, this potential can only become real if the orientation of sport include strategies aimed at achieving these goals.

Still, for sport to become truly inclusive, particularly among the most disadvantaged young people and/or subject to discrimination and/or with lower skills in the production of sporting performances, public policies for inclusion and prevention discrimination, abuse, and exclusion will be needed.

The concept of social capital, initially proposed by Pierre Bourdieu, has enormous potential in the conceptualization of the problem in the field of sport. In addition, the notion of "disaffiliation" associated with the loss of citizenship and exclusion proposed by Robert Castel seems to have some potential.

Obviously, for the study of social inclusion in or through sport makes use of the notion of affiliation associated with the exercise of citizenship, precisely because sport is a social space oriented to the creation of sociability and civic participation networks, in the production and reproduction of various identities, including the territorial and national.

Finally, I intended to show in this paper that the "social issue" in the field of sports has gained relevance in the institutional context. Additionally, a large number of projects and programs to promote social inclusion in and through sport have been created in European countries by diverse types of organizations. Considering these facts, a new field of research for the social science of sport is open and needs to be deepened.

\section{REFERENCES}

B Almeida, J. (2011). O Capital Social. Lisboa: INCM.

Arnold, P.J. (1998). Sport, Ethics and Education (2). London: Cassel.

Bourdieu, P. (1979). La Distinction Critique Sociale du Jugement. Paris: Les Éditions de Minuit.

Bourdieu, P. (1980). Le capital social: notes provisoires. Actes de la Recherche en Sciences Sociales, 31, 2-3.

\footnotetext{
${ }^{7}$ SPIN - Sport Inclusion Network (kicked off in 2011, March; duration 14 months). Involving migrants in mainstream sport institutions. Project funded by the European Commission (Sport Unit). Retrieved April 28, 2014, from http://www.footballforequality.org/sport-inclusion-spin/

${ }^{8}$ SPIN - Sport Inclusion Network (2012). Inclusion of Migrants in and through Sports A Guide to Good Practice. Retrieved April 28, 2014, from http://www.footballforequality.org/fileadmin/mediapool/pdf/spin/SPIN-GPG-sc.pdf
} 
Bourdieu, P. (1985). The forms of capital. In J.G. Richardson (org.), Handbook of Theory and Research for the Sociology of Education (pp. 241-58). Nova Iorque: Greenwood.

Castel, R. (1998). As Metamorfoses da Questão Social (9. ㄹ Edição). Petrópolis: Editora Vozes.

Dauncey, H., \& Hare, G. (Eds.) (1999). France and the 1998 World Cup: The National Impact of a World Sporting Event. London: Frank Cass.

Durkheim, É. (1975). Religion, Morale, Anomie, Textes 2. Paris: Les Éditions de Minuit.

Elias, N., \& Dunning, E. (1986). Quest for Excitement. Sport and Leisure in the Civilising Process. Oxford: Blackwell. Finn, G.P.T., \& Giulianotti R. (Eds.) (2000). Football Culture. Local Contests, Global Visions. London: Frank Cass.

Friedman, J. (2000). Cultural Identity e Global Process (4th Edition). London: Sage Publication.

Giulianotti, R., \& Robertson, R. (Eds.) (2007). Globalization and Sport. Oxford: Blackwell Publishing.

Haudenhuyse, R., Theeboom, M. \& Nols, Z. (2012). Sports-based interventions for socially vulnerable youth: Towards well-defined interventions with easy-to-follow outcomes?. International Review for the Sociology of Sport, 48(4), 471484.

Hylton, K. (2009). 'Race' and Sport. Critical Race Theory. London: Routledge.

Kassimeris, C. (2008). European Football in Black and White. Tackling Racism in Football. Lanham: Lexington Books. Maffesoli, M. (1988). Le temps des tribus. Le déclin de l'individualisme dans les sociétés postmodernes. Paris: La Table Ronde.

Marivoet, S. (1997a). Investimentos sociais em carreiras desportivas. Revista Horizonte, 76, 26-31.

Marivoet, S. (1997b). Dinâmicas sociais nos envolvimentos desportivos. Sociologia Problemas e Práticas, 23, $101-113$. Marivoet, S. (2006a). Euro $2004^{T M}$ Um evento global em Portugal. Lisboa: Livros Horizonte.

Marivoet, S. (2006b). UEFA Euro $2004{ }^{\mathrm{TM}}$ Portugal: The social construction of a sports mega-event and spectacle. In J. Horne \& W. Manzenreiter (Eds.), Sports Mega-Events. Social Scientific Analyses of a Global Phenomenon (pp. 127143). Oxford: Blackwell Publishing.

Marivoet, S. (2010). Sociological Approach on Sports Ethics in a Context of Social Change. Physical Culture and Sport. Studies and Research, 49, 39-52.

Marivoet, S. (2012). Inclusão Social no e pelo Desporto. Um Desafio do Século XXI. In P. M. Pinto (Coord.) Olímpico. Os Jogos num Percurso de Valores e de Significados (pp. 89-96). Porto: Edições Afrontamento.

Miller, T., Lawrence, G., McKay, J. \& Rowe D. (2001). Globalization and Sport. London: Sage Publications.

Northway, M.L., \& Weld, L. (1999). Testes Sociométricos. Lisboa: Livros Horizonte.

Pociello, C. et al. (1987). Sports et Société approche socio-culturelle des Pratiques. Paris: Éditions Vigot.

Portes, A. (2000). Capital Social: Origens e Aplicações na Sociedade Contemporânea. Sociologia Problema e Práticas, 33, 133-158.

Sanches, I. (2005). Compreender, Agir, Mudar, Incluir. Da investigação-acção à educação inclusiva. Revista Lusófona de Educação, 5, 127-142.

Sherry, E. (2010). (Re)engaging marginalized groups through sport: The Homeless World Cup. International Review for the Sociology of Sport, 45(1), 59-71.

Simon, R.L. (2004). Fair Play: The Ethics of Sport (2). Colorado: Westview.

\section{AUTHOR'S ADDRESS:}

\section{Salomé Marivoet}

CPES - Centro de Pesquisa e Estudos Sociais Faculdade de Educação Física e Desporto

Universidade Lusófona de Humanidades e Tecnologias, Portugal

Email: smarivoet@ulusofona.pt 